\title{
PSYCHOLOGICAL ANALYSIS FROM PORTRAIT
}

\author{
Guzalkhan Mukhammadjonova
}

Phd, Assosiate Professor, Fergana State University, Fergana Sity, Uzbekistan

\section{ABSTRACT}

The article examines the issue of the portrait of a creative person and its role in psycho-psychological analysis on the basis of the interpretation in literature of the great thinker, sheikh, a great representative of mystical literature, the poet Ahmad Yassaviy. Methods of creating portraits and experiments in this area are interpreted on the form of comparative-analytical method. The combination of images of the hero and his biography highlights the creative human psyche. The monologues, in particular, highlight the artisticaesthetic and artistic-conceptual role of monologue-memory and monologue-video in illuminating the heroic spiritual-psychological world.

KEYWORDS: - Ahmad Yassaviy, creative personality image, composition, portrait, dynamic portrait, contrast portrait, artistic-conceptual approach, mental image, psychological analysis, character, monologue, monologue-memory.

\section{INTRODUCTION}

Artistic creation is a complex, unique process consisting of closely interrelated and interdependent artistic elements, image factors. The artistic world created by the writer is a microcosm within the big universe, it has its own laws, each small grace has its own function. Every small element in the composition of the work requires that the detail be skillfully attached to the overall structure. This is a window that shows the author's skill.

Since literature is anthropology, its essence is to understand people, humanity and the meaning of coming and going. It is natural that these processes of perception and cognition are based on psycho-emotional changes. The first stages of understanding a person begin with the discovery of his image first and then his biography.
Although the image gives a certain idea, in order to understand the poem, it is necessary to understand its speech, actions, psyche, feelings. Only then can an estimate close to a clear picture emerge. It is inevitable that behind every image depicted in the play lies the ideological and artistic intention of the author. This intention is realized through various means.

\section{Methods}

It is known that a portrait (in French portraire) is a compositional element, a description of a person's appearance and inner world. There are different methods of portraiture, which are "one of the means of creating a full-fledged human image and revealing its character that comes to life in the reader's imagination" [1], and they include:

- $\quad$ static portrait; 
CURRENT RESEARCH JOURNAL OF PHILOLOGICAL SCIENCES 2(5): 79-84,

May 2021 DOI: https://doi.org/10.37547/philological-crjps-02-05-18

ISSN 2767-3758

(C)2021 Master Journals

\section{Crossref do) 81 Google}

Accepted25 $5^{\text {th }}$ May, 2021 \& Published 31 ${ }^{\text {th }}$ May, 2021

- dynamic portrait;

- contrast portrait.

Artistic portrait analysis is the key to discovering the psyche. The emotional, aesthetic effect inherent in a work of art is more vivid and impressive in the images of the psyche in the work. That is why such analyzes have attracted the attention of foreign and Uzbek literary critics. Literary critic A. Rasulov rightly noted, "Psychological signs are clearly visible in the portrait. The skillful artist illuminates his heart deeply through the portrait of the hero. There must be unity between the portrait and the direction of the character, and the portrait must serve to illuminate the heart of the protagonist "[2].

In mental analysis, the protagonist's mental experiences, expression of feelings, monologue, author's speech, author's attitude, 3rd person story-description, verbal and nonverbal means play an important role. The poetic skill of the writer is manifested in the deep revelation of the inner spiritual world of the main character.

The mastery of portraiture by L. Tolstoy and A. Tolstoy, whose works have a special place in Russian and world literature, is noteworthy. They try to express the portrait of the hero through his "dialectic of the heart". They tend to illuminate the character from their inner side, and the portrait is built from the protagonist's morals, actions, and struggles. The writers believed that the portrait came from the meaning of the words and followed this in their work, that is, "if the essence of the protagonist is correctly defined, his portrait will be drawn by the reader" [3].

Twentieth-century Uzbek prose is significant in that new methods and means of portraiture have been discovered. In the prose of our modern literature, it is especially significant that the artistic interpretation of the images of the creator has acquired an important artistic and aesthetic function. One of such works is Sadulla Siyaev's novel "Ahmad Yassaviy". This work which is published in the press under the title "The Last Journey of Yassaviy" was released in book form under the same name and attracted the attention of a number of literary critics [4]. The spirit of the period in which Yassaviy lived, based on a chronic plot similar to the way of thinking, depicts the period of maturity of the scholar. Childhood memories, past events are described retrospectively.

The composition of the work is unique. The novel consists of 36 chapters, each with a separate title. Each chapter begins with epigraphs that are similar in content. The selected epigraphs also contain the wisdom of the Holy Qur'an, Hadith, Oriental Wisdom, Folk Sayings, Yassaviy and other mystical literature in accordance with the theme of the novel.

The novel depicts the founder of the Yassaviyya sect, a sharp mind and a unique talent who lived a virtuous life all his life. The human qualities of Hoja Ahmad, who amazed everyone with his intelligence and religious knowledge and was able to follow the people, are more clearly reflected in the realities.

Although the historical personality of Yassaviy, the qualities of sainthood and piety are not sufficiently revealed in the play, his human qualities and spiritual experiences as a creator are deeply described. An emotionally saturated poetic speech is created on the basis of a number of poetic methods such as questioning, rhetorical questioning, rhetorical appeal, repetition. Even in the monologue and the author's speech in the work, it is not difficult to understand and feel the psyche of the creative person, the horns in his heart.

These poetic methods served to deeply express the author's artistic concept of a creative person. 
CURRENT RESEARCH JOURNAL OF PHILOLOGICAL SCIENCES 2(5): 79-84,

May 2021 DOI: https://doi.org/10.37547/philological-crjps-02-05-18

ISSN 2767-3758

(C)2021 Master Journals

\section{Crossref do) 81 Google}

Accepted25 ${ }^{\text {th }}$ May, 2021 \& Published 31 ${ }^{\text {th }}$ May, 2021

The author effectively uses the dynamic, static method of portraiture in the play. At the beginning of the work, a portrait in the language of the author-narrator gives an initial idea of the saint and sage Yassaviy, in other words, the protagonist of the work is introduced: "Zikri qalbi tufayli tili burro bo'ldi, hikmat aytdi. Turkiyda Latif va zarifona bayt aytib bo'lmas, deb mutakabbirlarning og ziga urdi. Shukrillahkim, hikmatlari mulki Turkiston aro manzur va mashhur...".

[By the command of his heart his speech became clear, he wrote poems with full of wisdom. The opinion of those who say that it is impossible to write a beautiful poem in Turkish has been proved wrong by him in practice. His poems are known and popular in Turkestan ...]

In the play, the image of the scholar is presented in a dynamic way from the point of view of the people, his wife and students. During ongoing events, glorious image of Yassaviyy rises. The portrait that created from the point of people`s view is unique which acquires a polyphonic image that is full of contrast. "In their illusion, saint had to be a man with a beard on his chest, a turban like a basket, and various verses inscribed on the sleeves and skirts of his robe. Hazrat Sultan, on the other hand, was completely fragmented. In fact, he had calm and thoughtful outlook, staring at people with tired eyes because of extreme amount of reading. He is wearing a white, thin turban. He also had a beard. Blue belt on his waist. He had slim body".

But this small body embodies great love, responsibility, courage and devotion. The author thus connects the celestial image of the saint to the earthly view.

The portrait lines given during the work show the attitude to reality, mental and emotional experiences. The sheikh's dark face darkened. His lips moved involuntarily and sweat appeared like a pearl on his forehead ". The moment of intense mental tension that has reached the level of kissing and swearing the Qur'an to realize the truth is appropriately described with great force of influence to the situation. The change in the face of the sheikh, who has been burnt out of a state of injustice, uncertainty, and distance from anxiety, is given by the thickening of the blacks of intense anguish. The emotional change that began with the darkening of the dark face is explained by the silent trembling of the lips, the appearance of "pearly sweat". It is known from psychological and physiological conditions that sweating is a strong manifestation of emotional arousal. The resemblance of sweat to a pearl shows both a strong level of suffering and emotion, and a glorification of the blessed one, reflecting the author's positive emotions and attitude towards him.

The portrait from Ruqiyabibi's point of view reflects her boundless love for the head of the family as a woman. This clearly shows Yassaviy's attitude towards the family and women. "... thank God, it's been twenty years since they put their heads on the same pillow. During these twenty years, the Sheikh did not allow her to perform any duties other than motherhood. ... he has not forgotten their habits, whether he has learned and done his service in exile. He takes care of his clothes by himself... These portrait lines are an expression of the family bond between intelligent women Ruqiyabibi and Yassaviy, who consider it a reward for them to serve their spouses honestly.

In three places in the play, Yassaviy's poetic nature and psyche are described in lyrical pathos. It reflects the qualities of a mystic who loves nature and the country, loves and values life, cares for his people. As A. Rasulov rightly points out, Roman thought grew up on the premise that "inspiration is given to saints." The play honestly reflects the courage of the saint and poet Yassaviy, his approach to every activity with inspiration and responsibility. In every 
CURRENT RESEARCH JOURNAL OF PHILOLOGICAL SCIENCES 2(5): 79-84,

May 2021 DOI: https://doi.org/10.37547/philological-crjps-02-05-18

ISSN 2767-3758

(C)2021 Master Journals

\section{Crossref do) 81 Google}

Accepted25 ${ }^{\text {th }}$ May, 2021 \& Published 31 ${ }^{\text {th }}$ May, 2021

description of Yassaviy, great amazement, great love, creative vision, intellectual vigilance and sharp observation are reflected.

Yassaviy's imaginary world is vast. He also feels like he is standing on the roof of the mosque on his great dream - Mount Arafat. He rides on a fantasy horse, traveling in seven climates, nine heavens. These images reflect his creative and emotional meaning and thinking.

"Heart of the Sheikh felt loneliness. But his psyche was clear. He turned to the four sides, he looked again and again at the city, which was still in a deep sleep. It was like his speechless goodbye to the city. Then he hurried downstairs. " This portrait, given by the narrator, has a symbolic-philosophical meaning.

The images of his psyche given after the farewell of the saint on his way to his final destination give great poetic meaning. The people, who has tried all his life to awaken the people from their slumber and to lead them to spiritual perfection, imagines that the sun of his life is fading, that he is falling from the stage of life, regretting that his life has not been fulfilled. "Looking the city again and again" is a very emotional image of despair. This portrait is sign to end of the work as well as the fate of the protagonist.

The writer who has a deep knowledge about character of the protagonist describes his inner monologue, the thoughts that pass through his mind. In the novel, the author effectively used the types of internal monologue, monologuememory, monologue-reflection, monologueimaginary dialogue, monologue-inspection, and it served to perfectly express the spiritual world of Yassaviy. We called the image of Yassaviy`s leaving from his homeland as a farewell. After all, it allows you to call it like that in essence. In these images, the author was able to enter the spiritual world, the heart of his protagonist and accept his pain, his feelings, as his own in a whole. In our opinion, this situation can demonstrate scientist's statement below: "the artist enters the heart of the hero, evaluates him, express his thoughts" [5].

First of all, in a work of art, the writer seeks to enter into the essence of the character. When the character of the protagonist becomes clear, his portrait "appears" and his originality in speech is "heard", psychological signs appear. Importantly, the writer understands the diversity of the character's language, knowing exactly which words will or will not be included his or her vocabulary. Although in some parts of the work there are instances of Yassaviy's speech deviating from coordination with the language of the period in which he lived, speech in throughout the work suits to a saint's verbal conditions. The severity of various trials, deep observation, great love for the Creator and his creatures (people, country), devotion and "heartbreak", humility in the speeches of Yassaviy show the gradual development of character.

"In literature, even a portrait of a single image is a combination of the real people's appearance or features of those who have seen and known them in real life; it is created by choosing from their images and embodying them in a specific hero. "[6] However, such an approach is slightly different in creating the image of historical figures. It is known that a person who has lived in real life acts as a prototype in creating the image of a historical figure. This is especially true of the lives of great historical figures. In the creation of such images, the method of aggregation, the term typification, should be used with caution. Because great historical figures are essentially typical statues.

As N.V. Gogol rightly points out, "a writer never draws a portrait from a simple copy. He creates portraits. " In creating a portrait, a new person creates a portrait by collecting, generalizing and creatively reconstructing the characters and 
CURRENT RESEARCH JOURNAL OF PHILOLOGICAL SCIENCES 2(5): 79-84,

May 2021 DOI: https://doi.org/10.37547/philological-crjps-02-05-18

ISSN 2767-3758

(C)2021 Master Journals

\section{Crossref do) 81 Google}

Accepted25 $5^{\text {th }}$ May, 2021 \& Published 31 ${ }^{\text {th }}$ May, 2021

qualities of several people in life, just like bees. Literary critic H. Umurov compares the work of writers in this process to the selectors. It means that they take the characteristics of people alive and confuse them with another living character, resulting in a completely new image.

\section{Conclusion}

The issue of artistic interpretation of historical images is a matter of historical truth and artistic fabric. In more precise, the historical fact, the reliance on the data itself loses the artistic value of the work, but in the process it is possible to maintain the balance of authenticity and vitality, as it is impossible to create a poetic world without artistic fabric. Portraits of historical figures are created on the basis of historical sources, literature and interpretations in the memory of the people, but the author's imagination will show its relevance if it comes from his ideological, artistic intentions and meaning.

In conclusion, the portrait is an important compositional element that gives an idea of the image as well as the key that reveals its spiritual world. In addition to providing information about the protagonists of the work, he is an expositionist, showing the development of reality and attitudes to situation, gradually demonstrating the development of character, expressing the conflict and collection of emotions, works as a sign of future reality. The masterly portrait is a testament to the writer's unique stylistic skills.

\section{REFERENCES}

1. Quronov D., Mamajonov Z., Sheraliyeva M. Adabiyotshunoslik T.,"Akademnashr", 2010. Б. 226.

2. Rasulov A. Badiylik - bezavol yangilik. -
T.: Sharq. 2007. B.. 187.

3. Русские писатели о литературном труде. Том 4, Л., 1957. Стр.490.

4. Rasulov A. Badiylik - bezavol yangilik. T.: Sharq. 2007.; Solijonov Y. Ko`zgudagi hayot. T., 2013.

5. Rasulov A. Badiylik - bezavol yangilik. T.: Sharq. 2007. B..194.

6. Umirov H. Badiiy ijod asoslari. T., "O’zbekiston", 2001, Б.80

7. Siyoyev S. Ahmad Yassaviy. - T .: "Yangi asr avlodi" 2019.

8. Mannopov, I. S. (2021). The Term "Hikmat",("Wisdom") Is Interpreted By Khoja Ahmad Yassaviy And His Followers. The American Journal of Social Science and Education Innovations, 3(04), 258-263.

9. Oripova, G. (2019). UZBEK POETRY AND THE WORLD LITERATURE IN THE YEARS OF INDEPENDENCE. Scientific Journal of Polonia University, 32(1), 116-120.

10. Mukhammadjonova Guzalkhan (2020) THE IMAGE OF A CREATIVE PERSON IN THE POETRY OF ERKIN VOHIDOV. ACADEMICA: An International Multidisciplinary Research Jurnal. Volume: 10 /Issue:11/. - India, 2020/ -P. 671-678.

11. Murodilovna O. G. Melody and musicality in Lirycs //ACADEMICIA: An International Multidisciplinary Research Journal. - 2020. - T. 10. - №. 11. - C. 656-664.

12. Mukhammadjonova, G. (2020, December). ARTISTIC INTERPRETATION OF THE CREATIVE CONCEPT IN WORLD LITERATURE. In Конференции.

13. Qayumov A. CREATING OF A NATIONAL CHARACTER THROUGH MEANS OF LITERATURE //Theoretical \& Applied Science. - 2018. - №. 1. - C. 235-240. 
CURRENT RESEARCH JOURNAL OF PHILOLOGICAL SCIENCES 2(5): 79-84,

May 2021 DOI: https://doi.org/10.37547/philological-crjps-02-05-18

ISSN 2767-3758

(C)2021 Master Journals

Crossref dol 81 Google

Accepted25th May, 2021 \& Published 31 th May, 2021

14. Guzalkhan, M (2021, April).CREATIVE PERSON AND THE HARD WORK OF CREATIVITY. In Evro-Asia Conferences (Vol.4,No.1,pp.239-240). 